This item was submitted to Loughborough's Research Repository by the author.

Items in Figshare are protected by copyright, with all rights reserved, unless otherwise indicated.

\title{
Engaging with the EU in order to minimise its impact: sport and the negotiation of the Treaty of Lisbon
}

PLEASE CITE THE PUBLISHED VERSION

http://dx.doi.org/10.1080/13501763.2011.609710

PUBLISHER

Routledge (@ Taylor and Francis)

VERSION

AM (Accepted Manuscript)

LICENCE

CC BY-NC-ND 4.0

REPOSITORY RECORD

Garcia, Borja, and Stephen Weatherill. 2019. "Engaging with the EU in Order to Minimise Its Impact: Sport and the Negotiation of the Treaty of Lisbon". figshare. https://hdl.handle.net/2134/8286. 
This item was submitted to Loughborough's Institutional Repository (https://dspace.lboro.ac.uk/) by the author and is made available under the following Creative Commons Licence conditions.

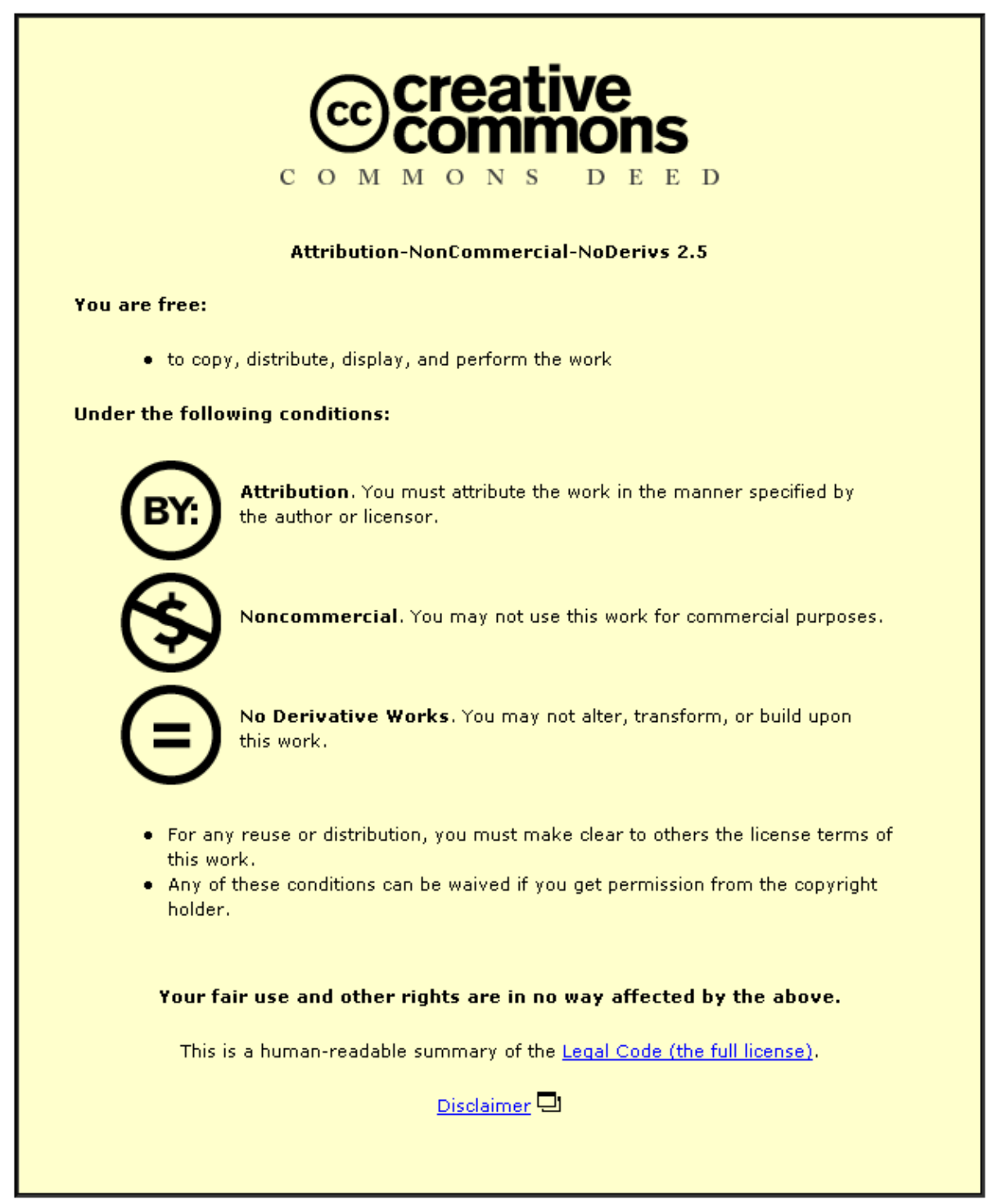

For the full text of this licence, please go to: http://creativecommons.org/licenses/by-nc-nd/2.5/ 


\title{
Engaging with the EU in order to minimise its impact: sport and the negotiation of the Treaty of Lisbon
}

Borja García and Stephen Weatherill

\begin{abstract}
The absence of explicit reference to sport in the EU Treaties has allowed the Court and the Commission room to require sport to adjust to the standards required by EU law. Sporting federations typically assert a need for a wider zone of autonomy than the Court and Commission have been prepared to grant, but, unable to persuade the Member States that they deserve exemption from the application of the Treaty, sports bodies have increasingly been induced to develop strategies of coexistence with the EU. This article shows how they were able to exert influence in both the Convention on the Future of Europe and the subsequent intergovernmental conference in order to secure recognition of sport's special characteristics within the Treaty, albeit in ambiguous form. Sports bodies engage with the EU precisely in order to minimise its impact. The relevant provisions of Treaty of Lisbon dealing with sport are examined to show that they leave open scope for future contestation about the interaction between EU law and policy and systems of sports governance.
\end{abstract}

KEY WORDS Convention on the Future of Europe, Intergovernmental conference; Lisbon Treaty; lobbying; sport 


\section{INTRODUCTION}

The European Union (EU) operates according to the principle of conferral found in Article 5 of the Treaty on the European Union (TEU). This means that it may act only in areas where its treaties so authorise. Until the entry into force of the Lisbon Treaty on 1 December 2009 sport was not even mentioned in the Treaty. Nevertheless first the Court of Justice and subsequently the Commission have insisted that in so far as sport constitutes an economic activity it falls within the scope of the Treaty. Accordingly the increasing financial clout of professional sport has brought with it increasing vulnerability to litigation driven by players, clubs and broadcasters. In so far as practices have been found incompatible with EU law significant change has been demanded within sport. So, famously, the Court's 1995 ruling in Bosman ${ }^{1}$ required the abandonment of direct discrimination on the basis of nationality in club football and the adjustment of the player transfer system. Sport bodies have long resented the intervention of EU institutions, for it constitutes a curtailment of the cherished autonomy of sport (see Chappelet 2010: 11-20 and 33-37). That autonomy is lost in so far as the EU treaties apply, and the consequence is the creation of two ‘separate territories': a territory for sporting autonomy and a territory for legal intervention (Parrish 2003a: 3, Weatherill 2007). Although both the Court and the Commission accept that sport is in some respects distinct from 'normal' industries they have typically taken a much narrower view of the special character of sport than that pressed upon them by sports federations, who typically criticise intervention as inadequately sensitive to the peculiar characteristics of sport (for example UEFA 2007). The contest, then, is over the extent to which the territory for sporting autonomy should be invaded by legal intervention. 
Governing bodies in sport have enjoyed no success in persuading the Court or the Commission that sport is of no concern to the EU, though they have enjoyed some success in arguing that particular challenged practices are compatible with the Treaty. This suggests that an approach based on acceptance in principle of the EU's proper involvement in sport combined with strategies to persuade its institutions that sporting practices are not incompatible with EU law might offer the most rational way forward.

Engaging with the EU in order to soften its intrusive effect was the principal strategy deployed directly and indirectly by sports organisations in the process of negotiation that led from the Convention on the Future of Europe to the Treaty of Lisbon, which has for the first time brought sport explicitly within the Treaties (see García 2007a). It may seem a paradox that actors whose main aim is to shelter their territory from incursion by the EU should be willing to embrace explicit inclusion of their industry in the Treaty. This, however, is rational once one understands that the structure of the Treaty, and in particular its broad functionally-driven emphasis on building an internal market, asserts a textually uncontrolled competence to regulate many sectors which are not explicitly within its reach. Including sport in the text of the Treaty is an attempt to exercise control over the direction taken by the Court and the Commission. This article explores the methods chosen by sport bodies and reveals that they have been able to exercise significant political leverage in recent negotiations, albeit that the ultimate prize, exemption from the Treaty, remains inaccessible.

The article analyses legal and policy documents and the empirical presentation is supported with information selected from a total of 45 semi-structured interviews with officials from EU institutions, national governments and sports organisations 
conducted during the Treaty negotiations between May 2004 and February 2007. The relevance of the data obtained in the interviews (and presented in this article) was confirmed through a process of respondent validation, to ensure the accuracy of our narrative.

The article proceeds in four steps. First we review the origins of EU sports law and policy. Second, the article explores the efforts of the sporting movement to gain Treaty recognition at Amsterdam, Nice and in the Convention on the Future of Europe. Third, the article explores the negotiations that led to the inclusion of sport in the Treaty of Lisbon. Finally, we assess the consequences of the relevant provision, Article 165 of the Treaty on the Functioning of the European Union (TFEU), the ambiguity of which promises further episodes in which sport bodies will seek to engage with the EU's institutions in order to persuade them to play a limited interventionist role.

\section{THE CONTESTED GROWTH OF EU SPORTS LAW AND POLICY}

In its first ever ruling on sport, Walrave and Koch, ${ }^{2}$ the Court concluded that even though the Treaty did not mention sport, its practice fell within its scope in so far as it constitutes an economic activity. This landmark ruling set the scene for a potentially broad basis of review of sporting practices against the standards demanded by EU law. However, the fact that a matter falls within the scope of EU law does not necessarily mean it is incompatible with it. In Walrave and Koch the Court proceeded to consider the particular matter at hand, the limitation of national representative teams to nationals of a particular country. This, one might suppose, offended a 
foundational value of the Treaty, the prohibition against nationality-based discrimination. However, the Court added that such a rule 'does not affect the composition of sport teams, in particular national teams, the formation of which is a question of purely sporting interest' (para. 8). There is therefore room for sport to show why it is different from normal industries: in this instance, nationality discrimination defines the very nature of the activity and consequently it escapes prohibition.

This legal model allows for a cohabitation of sporting regulations and EU law. Despite debate about the nature of this so-called ‘sporting exception’ (see Parrish and Miettinen 2007), its basic definition is relatively straightforward: Once it is demonstrated that a sporting practice exerts economic effects it falls within the scope of the Treaty. It then falls to the sports regulator to show a justification for the measure - and the justification may properly include reliance on material and concerns that are peculiar to sport.

The famous ruling in Bosman ${ }^{3}$ fits this model. The Court considered that rules governing the transfer of players and rules requiring nationality-based discrimination in club football exerted effects on player mobility and contractual negotiation. They therefore fell within the scope of the Treaty. This did not mean they were unlawful: it meant only that they required justification. The Court accepted that 'the aims of maintaining a balance between clubs by preserving a certain degree of equality and uncertainty as to results and of encouraging the recruitment and training of young players must be accepted as legitimate' (para. 106). While finding that the particular practices impugned in Bosman fell foul of the Treaty because they did not adequately contribute to these legitimate aims, the Court showed itself receptive to embrace of 
the special features of sport, even though these were not explicitly recognised by the Treaty.

In similar vein the Court in Meca-Medina and Majcen $v$ Commission ${ }^{4}$ held that the economic damage the application of anti-doping rules may exert on an individual athlete means that they cannot be placed beyond the reach of the Treaty. However, it accepted that such rules may be essential for the proper functioning of a sport. It had not been shown that the challenged anti-doping rules went beyond what was necessary for the organisation of the sport. As the Court put it, restrictions imposed by sports federations 'must be limited to what is necessary to ensure the proper conduct of competitive sport' (para. 47). This is a statement of the conditional autonomy of sports federations under the Treaty. And, of the highest significance, it implies the need for a case-by-case analysis of sporting practices rather than any general possibility of exemption (Wathelet 2006, European Commission 2007a).

The Commission, following the Court's lead, plays an important role in controlling sporting autonomy pursuant to the Treaty competition rules. It took account of sport's peculiar economics in its ENIC/UEFA decision ${ }^{5}$, in which it concluded that rules forbidding multiple ownership of football clubs suppressed demand but were indispensable to the maintenance of a credible competition marked by uncertainty as to the outcome of matches. A competition's basic character would be shattered were consumers to suspect collusion. Sporting practices typically have an economic effect, but within the area of overlap between EU law and 'internal' sports law there is room for recognition of features of sport which may differ from 'normal' industries. 


\section{EU SPORTS POLICY IN THE MAKING}

An emerging 'policy on sport' is the product of complex and dynamic interactions which may usefully be compared with policy formation in other sectors (Meier 2009), albeit that its character is influenced by the eccentric development generated by the Treaty's absence of any sports-specific material and the essentially incremental nature of litigation and complaint-handling (Van den Bogaert and Vermeersch 2006).

Sporting bodies have frequently objected to the very fact of EU involvement. This, however, is fruitless protest unless the Court abandons its approach which locates practices with an economic effect within the scope of the Treaty. This seems highly improbable. They have also complained that the EU institutions misperceive the nature of sport according to an economic bias inherent in the Treaty; and they believe that the case-by-case approach confirmed by the Court in Meca-Medina exposes them to uncertainty (Zylberstein 2007). Their concerns are rooted in their obligation to defend sporting practices on the terms dictated by EU law.

The scale of the problem is open to dispute. The impact of EU law is not always transformative. Anti-doping procedures were not outlawed by Meca-Medina; restraining multiple ownership of clubs was authorised by ENIC/UEFA. Even where a violation of the Treaty is established it is characteristic that the Court does not dictate how sporting bodies shall behave - its role is limited to deciding whether particular practices may not be pursued. So after Bosman the transfer system was not abandoned, but rather adjusted by the industry itself; in particular sports bodies were able to retain rules designed to protect contractual stability against players wishing to move without club consent (Brand and Niemann 2007). For some sports bodies, 
UEFA in particular, a strategy of co-operation with the EU has been chosen as the most promising way to promote awareness of sporting exceptionalism in the decisional practice of the EU’s institutions (García 2007b). This concern to work with the EU's institutions in order to restrain their interventionist bite is visible in the strategies chosen by sports bodies in the long review process that led to the entry into force of the Lisbon Treaty in 2009.

\section{THE INSERTION OF SPORT INTO THE TREATY: BEFORE LISBON}

\section{The Amsterdam and Nice declarations}

Judgments of the Court which interpret provisions of the Treaty carry entrenched force in the sense that they can be altered only by the Member States acting unanimously at times of Treaty revision. It is rare indeed that consensus can be assembled at the necessary moment, and the Court's judgments on sport have never been set aside in this way. But subtler forms of influence may be pursued. Failing to convince the Court and Commission of their case for exemption from the application of EU law, governing bodies resorted to politicisation of what was initially a legal and regulatory process (Parrish 2003a, Ch. 6). It is within this political turn that the efforts of sporting bodies to achieve Treaty recognition for sport (with the ultimate goal of controlling the Court and Commission's interference) have to be understood.

Concern to introduce an explicit mention of sport in the Treaties dates back to the mid 1980s. The current president of the International Olympic Committee (IOC), Jacques Rogge, who was at that time chairing the association of European Olympic Committees (EOC), played a key role in raising sport's awareness of the value of such change. He also drove the first lobbying efforts aimed at national governments under 
the umbrella of both the EOC and the European Non-Governmental Sport Organisations (ENGSO): 'Some contacts were made during the Inter Governmental Conference (IGC) leading to the Maastricht Treaty, but the Member States did not contemplate sport as a priority at all. In any case this was just a first contact, because the real discussions did not really start until about 1992 or 1993 ' ${ }^{6}$

The argument of the sporting movement has been historically built around two concepts: the specificity of sport and the autonomy of sports federations as regulators within their discipline. To promote these ideas, an intensive lobbying strategy was designed, taking into account the multi-level nature of the EU, the resources of sport organisations in Brussels and, especially, their contacts at national level through national federations and National Olympic Committees. ${ }^{7}$ The so-called sporting movement is perfectly equipped to engage with the EU machinery, for it presents an almost perfect match for the EU’s multilevel structures. Contacts were designed with a wide range of EU policy actors in order to nurture a constant dialogue. High level political contacts between the IOC president, European Commissioners and EU Heads of State and Government were developed. At the same time, national sports bodies were mobilised to lobby their respective national governments and, where possible, their representatives in the European Parliament.

By the time of the Nice Treaty, the Convention and the Lisbon Treaty, the contacts between the sporting movement and EU institutions in relation to Treaty change were fluid. As Kingdon (1995: 128-129) points out, issues are more likely to be considered on political agendas after a period of 'softening-up’. Political leaders (especially from Germany and France) were persuaded to bring sport into the negotiations that led to 
both the Amsterdam and the Nice Treaties. In the former case, it was 'probably too early for the case of sport', whilst in the latter 'political negotiations on institutional reform did not allow much time for other issues'. ${ }^{8}$ Nevertheless, in the European Council political leaders expressed a vision of the relationship between EU law and sport.

The Declaration on Sport attached to the Amsterdam Treaty asserts that 'the Conference emphasises the social significance of sport, in particular its role in forging identity and bringing people together. The Conference therefore calls on the bodies of the European Union to listen to sports associations when important questions affecting sport are at issue. In this connection, special consideration should be given to the particular characteristics of amateur sport'.

In the months leading to the Nice European Council of 2000, the sporting movement increased its efforts to achieve recognition in the Treaty. The IOC, the EOC and ENGSO presented in February 2000 a common declaration to the governments of the Member States; this argument was reinstated in July through a letter sent by IOC President Juán Antonio Samaranch to the French President (Miège 2001: 183). The support of the French presidency and its minister of sport, Mrs. Buffet, was essential to ensure incorporation of sport on to the agenda of the IGC and the European Council (Miège 2001: 184). The Declaration on 'the specific characteristics of sport and its social function in Europe, of which account should be taken in implementing common policies' annexed to the Conclusions of the Nice European Council held in December 2000 is a more elaborate document ( 3 pages, as compared to the mere 50 words of Amsterdam), which is symptomatic of the rising importance of sport on the EU 
political agenda. The Nice declaration reveals a similar tone to Amsterdam's. The institutions are called to 'take account of the social, educational and cultural functions inherent in sport and making it special, in order that the code of ethics and the solidarity essential to the preservation of its social role may be respected and nurtured.' The European Council calls also for the preservation of 'the cohesion and ties of solidarity binding the practice of sports at every level'.

These statements demonstrated that the tension between the EU's absence of explicit competence in the field of sport and the activity of its Court and Commission in applying the rules on free movement and competition had squeezed out a political response. Both Declarations, however, are formally non-binding and their content is vague and aspirational. They do not subvert the application of the fundamental Treaty rules to sport. Indeed the Court rushed to make this point, finding the Amsterdam Declaration 'consistent' with its own case law. ${ }^{9}$ Neither the Amsterdam nor the Nice Declaration was remotely close to the prize coveted by sport federations - partial or (most glittering of all) total exemption from the application of the rules of the Treaty. Yet for sport organisations both declarations were positive, for 'the support of Member States had increased from Amsterdam to Nice'. ${ }^{10}$

\section{Sport at the Convention on the Future of Europe}

The Convention on the Future of Europe accepted that the EU should acquire some formal competence in the field of sport; this, like so much of the Convention's work, was then reflected in the agreed text of the Treaty establishing a Constitution; and this, like so much of the Treaty establishing a Constitution, then found its way into the 
Treaty of Lisbon. The involvement in the negotiations of parties with interests in sport was largely informal, even hidden, yet highly effective. They did not secure exemption. But they did secure recognition of sport's special character.

The Convention opened in February 2002. A 'Digest of contributions to the Forum', prepared in the summer of 2002 in advance of a plenary session on civil society, blandly advised of a 'call for a specific legal basis for support for sport'. ${ }^{11}$ In fact, sport was not a high-profile issue in the debates and even the few documents that referred to it were in the main confined to brief comment without elaboration. ${ }^{12}$ Those contributions which displayed more ambition were grouped around a common anxiety that legal intervention undermines the special character of sport. They were consequently inclined to more legally durable protection than was provided by the Amsterdam and Nice Declarations. ${ }^{13}$ This tone is consistent with that typically advanced by sporting federations, and it underlines the impression that, for sports bodies, EU intervention is better controlled by explicit provisions written into the Treaty than by the long-standing pattern which had left sport outside the formal text of the Treaty.

The Praesidium presented a 'preliminary draft Constitutional Treaty' to a plenary session on 28 October 2002. There was no place for sport. However, the draft text proposed by the Praesidium and released on 6 February 2003 inserted sport into Part I of the Treaty as an area where the EU would be competent to take 'supporting action' (Article III-282 of the Treaty establishing a Constitution). 
This is the first of two occasions in the progress of negotiation where those pressing the interests of sport were able to secure adjustment as a result of well-targeted lobbying. An Annex to the text of 6 February 2003 explained that the insertion of sport followed on from the 'conclusions of Mr Christophersen's group'. ${ }^{14}$ This is a reference to Working Group V on Complementary Competencies, chaired by Henning Christophersen, a Danish politician and former member of the Commission. However, although within the Working Group Mr Speroni, an MEP representing the Italian Government, had pressed for sport to be included, ${ }^{15}$ the final report of the Working Group, published on 4 November 2002, was not persuaded. It declared that 'A proposal providing for the adoption of supporting measures with respect to international sports was not broadly supported' and sport was consequently excluded from the list of matters which the Working Group recommended be treated as apt for supporting measures adopted by the EU. ${ }^{16}$

The Chair of the Working Group believes that the inaccurate reference to its recommendation was made simply by mistake, and that one must look elsewhere to understand why sport was added to the list of proposed new competences between 28 October 2002 and 6 February 2003. ${ }^{17}$ It is difficult to identify an individual responsible for the inclusion of sport in the Praesidium's draft, but it is possible to trace the debates and influence of different actors that contributed to that decision. John Kingdon (1995) points out that policy decisions are exceptionally difficult to trace to a single point of origin or person, for there are normally several contributory factors. He argues, however, that it is possible to analyse the conditions that make decisions possible and the reasons why some policy options are preferred to alternatives. Kingdon's assertion is apt: the process at the Convention was dynamic, 
and sports bodies proved well-equipped to operate on but also beneath the formal record.

A variety of sports organisations presented written contributions to the so-called Forum of the Convention, where civil society bodies were invited to participate. The IOC, the National Olympic Committees of France and Germany, ENGSO and the Austrian Sports Confederation submitted co-ordinated documents, whilst major federations such as the Union of European Football Associations (UEFA) and the International Football Federation (FIFA) also contributed (Parrish 2003b: 39). These were on-record contributions for the benefit of all Convention members and, to some extent, they were a formal exercise. More importantly, from the very beginning of the Convention the sporting movement organised lobbying targeted at different levels:

We tackled this issue of the European Convention at quite an early stage. We [the IOC and EOC office] enabled our partners to take action towards the [Convention] representatives of their countries, we prepared the papers, the arguments, we talked to all the different kind of representatives in the Convention. We had meetings with members of the Praesidium of the Convention, with the secretariat, with the Commission $(\ldots)^{18}$

The importance of the working groups was recognised, but contacts were also built before and after Mr Christophersen’s group reported back to the Convention: 'We followed the working groups and for us the response of Christophersen was actually not very positive, but nevertheless we succeeded in putting our message across on other fronts'. ${ }^{19}$ Lobbying by sports organisations during the Convention combined 
high and low level meetings, as explained above, but towards the end it was the political weight of IOC President Jacques Rogge which pushed the Convention Praesidium to include sport:

We had meetings with members of the Praesidium of the Convention, for example [Klaus] Haensch, the German MEP represented in the Praesidium. We also had a meeting with chairman of the Convention, Giscard d'Estaing. But that was quite at the end, when Jacques Rogge met Giscard d'Estaing. Klaus Haensch was one of the main contacts for us and also Erwin Teufel, who used to be the Prime Minister of BadenWürttemberg, and was the representative of the Bundesländer in the Convention. We organised, for example, a meeting with all the German representatives in the Convention; we sat together with these people and we presented our position. That is what we also organised or initiated for other countries for our partners, so there was a lot going on. ${ }^{20}$

Crucially, the sporting movement's lobbying in favour of inclusion of sport in the Treaty was aligned with the agendas of Member States. In this respect, the support of European ministers of sport proved vital to move the debate forward, although not all Member States were convinced of the case:

It was quite a long effort. The sports ministers had debated in depth the necessity of having an article on sport since 2000, but it was probably after reaching an agreement on our participation in WADA in 2002 that we pushed with real determination for the article. It was a great common 
effort. I think that perhaps one of the decisive moments was the Greek presidency [first half of 2003]. The Greeks organised a sports ministers meeting in Brussels and they did a brilliant job because they also invited the Commission and the sporting movement. They presented the case for a Treaty article brilliantly, because Minister Beniselos, who is also Professor of Law back in Athens, analysed perfectly the level of EU competences that sport could get (...) It was a tough meeting, nonetheless. We faced opposition especially from the UK. The British team had reserves because they did not want to commit, even if it was informally, to any addition of new competences in the Treaty. They were very cautious (...) It was a difficult negotiation, but we managed to get the agreement, in principle, of the UK, which was almost a victory for all of us. ${ }^{21}$

With that agreement at a key moment in 2003, the sports ministers strengthened their political case, bringing the agendas together at the decisive moment of the Convention:

That Greek Presidency coincided with the works of the Convention. It was then when we [European sports ministers] intensified our political lobbying in the Convention, we had to convince as many people as posible. We submitted a declaration from Spanish and French Convention members in support of the inclusion of sport and tried our best, but the first draft did not incorporate sport. We had then to raise our level of lobbying at the highest level through the governments and thankfully with the collaboration of all of us the Praesidium finally accepted to incorporate sport into the Treaty. ${ }^{22}$ 
The European Commission Sports Unit also worked in favour of an article on sport. The political intervention of Commissioner Viviane Reding (then in charge of sport within her Education and Culture portfolio) influenced the Praesidium, especially through conversations with Michel Barnier and Antonio Vitorino, who were representing the Commission in the Praesidium. ${ }^{23}$ The Commission not only provided an important last push, but (in close consultation with sports ministers) it was also behind the wording of the article:

Jaime Andréu [former Head of the European Commission Sports Unit] would say it is his article, it is the Commission's wording, which perhaps is true but not the whole truth (...) He put it in circulation, so the wording, if you put it to the wording, probably comes from the [European Commission] sports unit. But the will to implement this article was a common project to prepare the will of these decision makers, was a common project of the sports organisations, sports ministers and the Commission. $^{24}$

Thus, the Praesidium's decision to incorporate sport in the February 2003 draft Constitution was largely unopposed, and probably also unnoticed by most members of the Convention: 'Sport is an important issue for us of course, but we always benefit from the fact that, at the end of the day, it is relatively marginal in the wider scheme of EU politics, so people do not necessarily pay excessive attention' ${ }^{25}$ Indeed it was declared in May 2003 that the drafts of new legal bases, including that pertaining to sport, had 'in general been well received' ${ }^{26}$ Sport's inclusion as an area in which the 
EU should be explicitly empowered was by now insufficiently contentious to emerge as a sticking-point.

The efforts of the European sports ministers to convince their own governments and then other Convention members, together with the determination of the European Commission's sports unit, complemented the case presented by sports organisations. There were certainly differences in the objectives of the several interested parties, as explained below, but they all shared a common objective to see sport recognised in the Treaty. The decision to incorporate sport in the final Convention draft confirms Greenwood's (2007: Chapters 1 and 5) view of effectiveness in EU lobbying, which points out that alignment of policy objectives may in some cases be more important than economic resources.

\section{Sport at the IGC}

The Convention over, the Draft Treaty establishing a Constitution for Europe submitted to the President of the European Council in Rome in July 2003 established sport as an area of 'supporting, coordinating or complementary action' and added detailed provisions in a new article under the title Education, Vocational Training, Youth and Sport (Article III-282). This provided that 'The Union shall contribute to the promotion of European sporting issues, given the social and educational function of sport'. Union action was to be aimed at 'developing the European dimension in sport, by promoting fairness in competitions and cooperation between sporting bodies and by protecting the physical and moral integrity of sportsmen and sportswomen, especially young sportsmen and sportswomen’. 
The ambition was plainly that an explicit reference to sport should help to preserve sport's autonomy, rather than because of any belief that the EU should assume a more active regulatory role. This is a strategy of empowering the EU in order to restrain it. However, the text agreed in 2003 was in this respect not satisfactory to some concerned to defend sport's interests. This is the second of two occasions in the progress of negotiation where those pressing the interests of sport were able to secure adjustment as a result of well-targeted lobbying. The Treaty establishing a Constitution finally agreed in late 2004 included sport alongside education, youth and vocational training as an 'area of supporting, coordinating or complementary action', while the substantive elaboration provided that 'The Union shall contribute to the promotion of European sporting issues, while taking account of the specific nature of sport, its structures based on voluntary activity and its social and educational function’ (authors’ emphasis).

What is the 'specific nature of sport'? The notion was aired at the Convention. In November 2002 a contribution by Duhamel and Beres simply proposed that the Union be committed to recognise 'the specificity of the sport' ${ }^{27}$ The phrase also appears in a small number of other contributions but its intended impact is not elaborated. ${ }^{28}$ In general 'specificity' is best understood as the 'next best' argument of sporting bodies after autonomy. Autonomy is a claim to immunity. Specificity is a claim to have the law moulded in application to meet sport's special concerns. However, the concept was excluded from the text finally agreed by the Convention in July 2003 and had to await agreement on the Treaty establishing a Constitution in December 2004 for its re-emergence, in the form of the 'specific nature of sport'. Why was it added after the Convention had concluded its work? 
The answer lies largely in lobbying by the IOC and the EOC, the support of the sports ministers and, above all, to the important figure of the Italian Mario Pescante. With the IGC under Italian presidency, Pescante had a perfect position, for he was President of the EOC and, at the same time, Italian sports secretary. Pescante was the sporting movement’s 'Trojan horse'. The Italian presidency (second half of 2003) organised an informal meeting of EU sports ministers in Florence, where the objective was to consider the amendment of the Convention's version of the article on sport. ${ }^{29}$ Before that meeting Pescante circulated a draft of a new version of the article. In it he put forward what could be considered the maximum ambition of the sporting movement. It contained references to both the autonomy and specificity of sport:

We were lucky that the IGC was under Italian presidency because Mario Pescante's work was extremely important and influential. The Italian presidency presented a new wording for the article, different to the Convention's. He [Pescante] wanted to include all our [i.e. the sports ministers'] objectives, namely sports autonomy, specificity, education and anti-doping. ${ }^{30}$

During that meeting in Florence the sports ministers first agreed to maintain the article on sport for the IGC and they then negotiated on the basis of Pescante's document:

We had to negotiate a lot because there was some opposition. We trimmed down the Italian proposal, but I would say we reached a general agreement. There was only opposition from the UK, Ireland and Denmark 
if I remember correctly. But it was more of a formal opposition. That was an informal meeting of sports ministers, so they were very cautious in not committing to anything formally. They said they had to report back. Yet, there was a general sense that we needed to recover that article on sport. I think it was also very important the agreement of the new Central and Eastern European Countries, who were already participating in our meetings. $^{31}$

The opposition of the British, Irish and Danish governments to the principles agreed in Florence was overcome with a mixture of peer pressure from the other Member States and high level lobbying by the IOC and the national Olympic Committees of the affected countries. The British case was quickly solved once the government realised it would be detrimental for the London 2012 bid to oppose the IOC. ${ }^{32}$ There was still some way to go towards the final wording of the article on sport. First, the informal agreement of the sports ministers had to be revised by the legal service and ratified by the Member State representatives in the IGC (i.e. the foreign affairs ministers). More importantly, the Commission was unhappy with the agreement in Florence: 'That text was difficult to accept, it gave too much space to sports organisations, we could never allow that with the case law of the Court, which is very clear' ${ }^{33}$ Plainly the Commission has no veto and would have been powerless had there existed a political consensus in favour of sweeping aside the Court's interventionist case law. However, as had already been plain in the drafting of the Nice Declaration, there was no real appetite among national governments to pursue such radical modification of the Treaty, and accordingly the legal and political preferences of the Commission carried weight with the sports ministers and with the 
IGC's legal services. Negotiation during the final months of the IGC further adjusted the text agreed in Florence:

The Commission was unhappy with the text we agreed in Florence. We had to negotiate with them before the end of the IGC. We set up a negotiating party between the Member States and the Commission that started to modify and trim down the text. Little by little, meeting by meeting we went on trying to fine tune the article. In the end we got to a text that the Commission was happy with and that we [the sports ministers] also accepted. Yes, it is short, perhaps we could have said more about autonomy or specificity, but it covers the objectives of the sports ministers. $^{34}$

The text agreed between the sports ministers and the Commission is what was finally accepted by the IGC in Naples in November 2003 and duly incorporated in the body of the Treaty establishing a Constitution. Thus, the reference to the specificity of sport that can be found in what is today Article 165 TFEU was rescued by the sports ministers negotiating in 2003 with the Commission on the basis of the proposal put forward by the sporting movement. It is a compromise in true EU style. It is also a story which reveals sport's lobbying expertise. The intensity of interaction described in this paper, conducted entirely unnoticed on the formal record of the Convention and the IGC, was skilfully guided through all available fora, most prominently the Convention but also the subsequent IGC, exploiting leverage over national governments and the Commission (in particular). Sports bodies deserve to be understood as part of the fabric of ‘élite pluralism’ which characterises EU interest 
politics (Mazey and Richardson 2006, Coen 2007). In addition the shaping of the outcome confirms the highly influential role played by the EU Presidency, both generally (Niemann and Mak 2010) and in the particular context of negotiation over Treaty revision (Beach 2005). Sport enjoyed the crucial advantage of an 'insider' within the IGC’s Italian Presidency, Mario Pescante.

\section{THE TREATY OF LISBON}

The Treaty establishing a Constitution, mortally wounded by its rejection in referenda in France and the Netherlands during 2005, was laid to rest in 2007. The Lisbon Treaty was agreed in 2007 and, after unsteadily clearing a series of political and constitutional hurdles, the Treaty entered into force on 1 December 2009.

The principal strategy behind the drafting of the Lisbon Treaty was that it should be sufficiently different from the Treaty establishing a Constitution to justify withdrawal of the promise of a referendum (everywhere but Ireland) but not so different that the substance of the planned institutional reforms would be lost. How different it truly was remains a matter of persisting controversy (Dougan 2008), but in the particular case of sport the narrative is one of consistency. What was agreed in the Treaty establishing a Constitution was left untouched in 2007 as the Lisbon Treaty was negotiated and agreed. The deals had been done: for sport, Lisbon left the package untouched.

The Lisbon Treaty therefore brings sport within the explicit reach of the founding Treaties for the first time. In formal terms, it is profoundly significant. However, the 
detailed content of this competence newly granted by the Member States to the EU is far less remarkable. Title XII of Part Three of the TFEU covers Education, Vocational Training, Youth and Sport. Article 165 TFEU stipulates that the Union 'shall contribute to the promotion of European sporting issues, while taking account of the specific nature of sport, its structures based on voluntary activity and its social and educational function'. And, pursuant to Article 165(2), Union action shall be aimed at 'developing the European dimension in sport, by promoting fairness and openness in sporting competitions and cooperation between bodies responsible for sports, and by protecting the physical and moral integrity of sportsmen and sportswomen, especially the youngest sportsmen and sportswomen.' Article 165(3) adds that the Union and the Member States 'shall foster cooperation with third countries and the competent international organisations in the field of education and sport, in particular the Council of Europe'.

\section{ASSESSMENT: A DECLARATION OF PEACE?}

A Treaty which ignored sport completely was a Treaty which, in the hands of the Court and the Commission, controlled sporting autonomy with some vigour. Absent political consensus conducive to granting sport exemption from the Treaty, the 'next best' solution for those engaged in sports governance was to write sport into the Treaty in a way that would constrain the interventionist tendencies of the EU's institutions. This is the motivation that drove the adjustments made by the Lisbon Treaty. 
However, the terms of the new provisions are sufficiently ambiguous to guarantee further disputes about the impact of EU law on sporting practices. This is no declaration of peace.

Article 165 TFEU creates a legislative competence pertaining to sport and allows a budget to be dedicated to sport. The first EU Sports Council met under Spanish Presidency in May 2010. However, there is no likelihood of dramatic change. The newly created legislative competence is 'supporting', the weakest type available to the EU under Article 6(e) TFEU. Article 165(4) TFEU adds that the Parliament and Council may adopt 'incentive measures’ but they may not harmonise laws concerning sport. There is no suggestion in the Treaty that the Union is equipped to play a powerful role in regulating sports governance. This is firmly in line with the plan mapped out by the Commission in its 2007 White Paper on Sport, designed to provide a framework for the EUs activities whether or not the Lisbon Treaty secured approval (European Commission 2007a, b). The White Paper, like the Nice Declaration before it, is pitched in terms which are deferential to the value of sites for the regulation of sport other than the EU in general and the Commission in particular. It declares that sporting organisations and Member States have a primary responsibility in the conduct of sporting affairs.

It is significant that after the Lisbon Treaty reforms sporting bodies can no longer claim that sport is none of the EU's business. Instead one would expect them to claim that it is the EU's business but only to a limited extent, and only in so far as respect is shown for its 'specific nature'. The key to the Lisbon adjustments will be whether they affect the interpretation of the Treaty provisions on free movement and 
competition which the Court and Commission have applied to sport ever since the Walrave ruling in 1974.

It is possible that the 'specific nature' of sport will be found to amount to nothing different from matters which the Court and Commission have in the past been prepared to admit to the legal analysis of the compatibility of sporting practices with the Treaty - such as the place of national representative teams and the need for uncertainty of outcome. Even in advance of the Lisbon Treaty, the Commission's 2007 White Paper included a section entitled 'The specificity of sport' (European Commission 2007a: para. 4.1). This is to be approached through 'two prisms', dealing with the specificity of sporting activities and of sporting rules (separate competitions for men and women, limitations on the number of participants in competitions, the need to ensure uncertainty concerning outcomes and to preserve a competitive balance between clubs taking part in the same competitions) and the specificity of sport structures (the autonomy and diversity of sport organisations, a pyramid structure of competitions from grassroots to elite level connected by solidarity mechanisms, the organisation of sport on a national basis, and the principle of a single federation per sport). A general exemption from the Treaty is 'neither possible nor warranted' (European Commission 2007b: 69, 78); and there is a need for case-by-case scrutiny. The problem from the perspective of sport is that these concessions to 'specificity' are made on the terms dictated by the decisions of the Court and the Commission. This anxiety had driven the Independent European Sport Review, published in 2006 (Arnaut 2006) and heavily influenced by UEFA, which deployed the discourse of 'specificity' in pressing for a wider exclusion from the Treaty than the case law of the Court admits (Miettinen 2006). The 2007 White Paper largely ignores this plea. 
Consequently it generated renewed criticism that the conditions imposed on sporting autonomy by EU law are inapt to take account of the particular features of sport and that in any event their case-by-case application breeds unpredictable disruption (Hill 2009). The fear for sports bodies is that the Lisbon reforms are simply more of the same.

After Lisbon the Treaty's explicit recognition of sport's 'specific nature' will doubtless provide the first line of defence. And it is at least possible that the Court and the Commission will be tempted to show a greater deference to sporting choices than they did prior to the entry into force of the Lisbon Treaty. Union action shall be aimed at 'developing the European dimension in sport, by promoting fairness and openness in sporting competitions and cooperation between bodies responsible for sports, and by protecting the physical and moral integrity of sportsmen and sportswomen, especially the youngest sportsmen and sportswomen.' This is a mix of the obscure and self-evident. 'Fairness' could be a glib notion which has no policy bite or it could convey a very specific commitment to competitive balance. Sports bodies might argue that practices which restrain competition should nonetheless be treated as compatible with the Treaty in so far as they achieve a better balanced distribution of wealth within a sport as a device to promote 'fairness'. This has particular resonance in the matter of sale of broadcasting rights, where sporting bodies have frequently though with mixed success argued that joint, rather than individual, selling should be treated as a justified means to raise income which can be spread in order to improve ‘solidarity' in the game (Parrish \& Miettinen 2009, Weatherill 2010). The problem for sports bodies is that the place where resolution of these finely balanced issues occurs is the place where it has always occurred: before the Commission or ultimately the 
Court. Sporting bodies have achieved a protection of sorts in the Treaty, but they have not escaped the grip of the EU institutional architecture.

\section{CONCLUSION}

On 30 November 2009, the day before the entry into force of the Lisbon Treaty, IOC President Jacques Rogge commented that 'It really is time to move from a case-bycase approach to an environment where the specific characteristics of sport can be taken into account properly'. ${ }^{35}$ This was quickly followed up by publication of a 'Common Position' on the implementation of the TFEU (Olympic and Sports Movement 2010). Twin themes animate the document: a desire for more concrete guidance on the impact of EU law and pressure for confirmation of the autonomy of sports organisations. It is declared (p. 2):

The Olympic and Sports Movement must be a key player in defining which sporting rules shall be recognised as specific, and accordingly are to be governed uniquely by sports federations. The intention is not to obtain an exemption from EU law, but a specific application of EU law to sport.

This is a good deal more subtle than past pleas for a sporting exemption, commonly accompanied by aggressive disdain for the EU’s pretensions. Moreover, as part of a strategy of ensuring participation and influence, it is proposed to extend existing cooperation between the Olympic and Sports Movement and the Commission to include also permanent consultation with the Parliament and the EU Sports Council. 
A failed strategy of 'keep the EU out!', which would have been realised only by the total exemption of sport from the EU Treaty, has been replaced by a preference to work more co-operatively while seeking to use the EU's own Treaty, and most of all its reference to the 'specific nature' of sport, as a basis for confining its intrusion. This was the story behind the negotiations at the Convention and again at the IGC, and it is the blueprint for the future. It is, however, not clear whether the Lisbon Treaty, despite bringing sport explicitly within the Treaty for the first time, has changed the scope or character of the conditional autonomy from EU law that sport has long been forced to tolerate. One may therefore predict a re-affirmation of strategies of cooperation with the EU's institutions, because ultimately sporting bodies will have to win their battles to protect their preferred methods of operation at the same venues as before, in Luxembourg and in Brussels.

\section{Bibliographical note:}

Borja García is Lecturer in Sport Management and Policy at Loughborough University.

Stephen Weatherill is Jacques Delors Professor of European Law at the University of Oxford.

\section{Address for correspondence:}

Borja García, School of Sport, Health and Exercise Sciences; Loughborough University, Leicestershire, LE11 3TU. b.garcia-garcia@lboro.ac.uk

Stephen Weatherill, Somerville College, Oxford, OX2 6HD. Stephen.weatherill@law.ox.ac.uk. 


\section{NOTES}

${ }^{1}$ Case C-415/93 [1995] ECR I-4921.

${ }^{2}$ Case 36/74 [1974] ECR 1405.

${ }^{3}$ Note 1 above.

${ }^{4}$ Case C-519/04 P [2006] ECR I-6991.

${ }^{5}$ COMP 37.806 ENIC/ UEFA, 27 June 2002.

${ }^{6}$ Interview, Christophe de Kepper, IOC senior official, Lausanne 16 February 2007.

${ }^{7}$ Interview, Christophe de Kepper, see note 6.

${ }^{8}$ Interview, Tilo Friedmann, former director of the EU Office of German Sports (now rebranded as EOC-EU Office), Brussels 11 May 2006.

${ }^{9}$ Cases C-51/96 \& C-191/97 Deliege v Ligue de Judo [2000] ECR I-2549 paras 41-42; Case C-176/96 Lehtonen et al v FRSB [2000] ECR I-2681 paras 32-33.

${ }^{10}$ Interview, Christophe de Kepper, see note 6.

${ }^{11}$ CONV 112/02 17 June 2002. Documentation is available via http://european-convention.eu.int/.

${ }^{12}$ See e.g. CONV 189/02 12 July 2002 (Hänsch et al), CONV 234/02 3 September 2002 (Duff), CONV 335/02 19 November 2002 (Ornella Paciotti), CONV 325/1/02/REV1 6 December 2002 (Brok), CONV 541/03 6 February 2003 (Brok), CONV 325/2/02/REV2 7 March 2003 (Brok), CONV 495/03 20 January 2003 (Teufel).

${ }^{13}$ CONV 33/02 17 April 2002 (Duhamel), CONV 337/02 10 October 2002 (Tajani), CONV 478/03 10 January 2003 (Haenel et al).

${ }^{14}$ http://european-convention.eu.int/docs/Treaty/cv00528.en03.pdf, page 18.

${ }^{15}$ See Working Group V Working Documents 25 and 29 (neither offers any reasoned explanation for bringing sport into the Treaty).

${ }^{16}$ CONV 375/1/02, http://register.consilium.eu.int/pdf/en/02/cv00/00375-r1en2.pdf.

${ }^{17}$ Personal communication to the authors from Mr Christophersen.

${ }^{18}$ Interview Tilo Friedmann, see note 8.

19 Ibid.

${ }^{20}$ Ibid. 
${ }^{21}$ Interview, Jacobo Beltrán, policy adviser to the Spanish sports minister, Madrid, 5 January 2007.

${ }^{22}$ Ibid.

${ }^{23}$ Interview, Yves Le Lostecque, former Deputy Head of Sports Unit, DG Education and Culture, European Commission, Brussels, 6 June 2006.

${ }^{24}$ Interview, Tilo Friedmann, see note 8. Also ratified by Jacobo Beltrán (see note 21) and Jose Maria Alises, policy advisor to the Spanish Sports Minister.

${ }^{25}$ Interview, Tilo Friedmann, see note 8.

${ }^{26}$ CONV 783/03 ‘Summary report on the plenary session’ 16 June 2003 p.12.

${ }^{27}$ CONV 398/02 12 November 2002 page 4.

${ }^{28}$ CONV 337/02 10 October 2002 (Tajani) ('specificita'); CONV 478/03 10 January 2003 (Haenel et al).

${ }^{29}$ Interviews: Jacobo Beltrán (see note 21), Tilo Friedmann (see note 8), Jaime Andréu, former Head of the European Commission Sports Unit, Brussels 20 March 2006.

${ }^{30}$ Interview, Jacobo Beltrán, see note 21. Pescante’s role has also been confirmed by Jaime Andréu and Tilo Friedmann (see note 29).

${ }^{31}$ Interview, Jacobo Beltrán, see note 21.

${ }^{32}$ Interview Tilo Friedmann, see note 8.

${ }^{33}$ Interview Jaime Andrew, see note 29.

${ }^{34}$ Interview Jacobo Beltrán, see note 21.

35 'Lisbon Treaty gives a boost to sport', 30 November 2009, https://www.sportsfeatures.com/presspoint/pressrelease/50491/lisbon-treaty-gives-a-boost-to-sport. 


\section{REFERENCES}

Arnaut, J. L. (2006) The Independent European Sport Review, http://www.independentfootballreview.com.

Beach, D. (2005) The Dynamics of European Integration: Why and When EU Institutions Matter, Basingstoke: Macmillan Publishers.

Brand, A. and Niemann, A. (2007) 'Europeanisation in the Societal/ Trans-national Realm: what European Integration Studies can get out of analysing football', Journal of Contemporary European Research 3(3): 182-201.

Chappelet, J.-L. (2010) Autonomy of Sport in Europe, Strasbourg: Council of Europe Publishing.

Coen, D. (2007) Special Issue: Empirical and Theoretical Studies in EU Lobbying, Journal of European Public Policy 14(3): 333-488.

Dougan, M. (2008) 'The Treaty of Lisbon 2007: Winning minds, not hearts', Common Market Law Review 45(3): 617-703.

European Commission (2007a) White Paper on Sport, COM (2007) 391 final, 11 July 2007. 
European Commission (2007b) Staff Working Document annexed to the White Paper on Sport, COM (2007) 391, 11 July 2007.

García, B. (2007a) 'From regulation to governance and representation: AgendaSetting and the EU's involvement in sport', Entertainment and Sports Law Journal 5(1):

http://www2.warwick.ac.uk/fac/soc/law/elj/eslj/issues/volume5/number1/garcia/\#a9.

García, B. (2007b) 'UEFA and the European Union: From confrontation to cooperation', Journal of Contemporary European Research 3(3): 202-23.

Greenwood, J. (2007) Interest Representation in the European Union, $2^{\text {nd }}$ edition, Basingstoke: Palgrave Macmillan.

Hill, J. (2009) ‘The European Commission’s White Paper on Sport: a step backwards for specificity?’, International Journal of Sport Policy 1(3): 253-66.

Kingdon, J. W. (1995) Agendas, Alternatives and Public Policies, 2nd edition, New York: Harper Collins Publishers.

Mazey, S., and Richardson, J. (2006) 'Interest groups and EU policy-making: organizational logic and venue shopping', in J. Richardson (ed), European Union: power and policymaking, London: Routledge, pp.247-65. 
Meier, H. (2009) 'Emergence, dynamics and impact of European sport policy perspectives from political science’, in S. Gardiner, R. Parrish and R. Siekmann (eds), EU, Sport, Law and Policy, The Hague: T M C Asser Press, pp. 7-34.

Miège, C. (2001) 'Le sport dans l’Union Européenne: Quelle exception sportive?’, Esprit 12 (280): 179-89.

Miettinen, S. (2006) 'The Independent European Sport Review: a critical overview’, International Sports Law Journal 2006/3-4: 57-62.

Niemann, A. and Mak, J. (2010) '(How’) do norms guide Presidency behaviour in EU negotiations?', Journal of European Public Policy 17(5):727-42.

Olympic and Sports Movement (2010) Common Position on the implementation of the new Treaty on the Functioning of the European Union on sport, IOC position paper, available at http://www.euoffice.eurolympic.org/cms/getfile.php?98.

Parrish, R. (2003a) Sports Law and Policy in the European Union, Manchester: Manchester University Press.

Parrish, R. (2003b) 'The birth of European Union sports law', Entertainment Law 2(2): 20-39.

Parrish, R. and Miettinen, S. (2007) The Sporting Exception in European Union Law, The Hague: T M C Asser Press. 
Parrish, R. and Miettinen, S. (2009) 'Sports broadcasting in Community law' in I. Blackshaw, S. Cornelius and R. Siekmann (eds), TV Rights and Sport, The Hague: T M C Asser Press, pp.9-34.

UEFA (2007) 'Sport Should Not Be Ruled by Judges: European Basketball, Football, Handball and Volleyball Are United in Defending the European Sports Model', Media Release 70, 9 May 2007, available at http://www.uefa.com/newsfiles/536655.pdf.

Van den Bogaert, S. and Vermeersch, A. (2006) 'Sport and the European Treaty: A tale of uneasy bedfellows', European Law Review 31(6): 821-40.

Wathelet, M. (2006) 'L’arrêt Meca-Medina et Majcen: plus qu’un coup dans l'eau', Revue de Jurisprudence de Liége, Mons et Bruxelles 41: 1799-1809.

Weatherill, S. (2007) 'On overlapping legal orders: what is the purely sporting rule?', in B. Bogusz, A. Cygan and E. Szyszczak (eds), The Regulation of Sport in the EU, Cheltenham: Edward Elgar, pp.48-73.

Weatherill, S. (2010) 'Fairness, openness and the specific nature of sport: does the Lisbon Treaty change EU sports law?’, International Sports Law Journal 2010/3-4: 16. 
Zylberstein, J. (2007) 'Collision entre idéaux sportifs et continges économiques dans l'arret Meca-Medina', Cahiers de Droit Européen 43(1-2): 218-38. 